\title{
Intestinal Phospholipase, a Novel Enzyme
}

\author{
Charles M. Mansbach, II, Veterans Administration Hospital and Department of \\ Medicine, Division of Gastroenterology, Duke University Medical Center, \\ Durham, North Carolina 27710 \\ Gerard Pieroni and Robert Verger, Centre de Biochimie et de Biologie \\ Moléculaire, 13274 Marseille Cedex 2, France
}

A B S T R A C T We evaluated phospholipase activity in the intestine of rats and other species. Phospholipase activity was assayed by a surface barostat technique or an egg yolk titration system. Mucosal activity was found only by the surface barostat technique with phosphatidylglycerol as substrate; it was not found with phosphatidylcholine as substrate in assays by either technique. In gut luminal fluid activity was found when both phosphatidylcholine and phosphatidylglycerol were used as substrate in assays by the surface barostat technique, and phosphatidylcholine as substrate yielded activity in egg yolk titration. In rats in which pancreatic juice had been diverted, mucosal and gut luminal phospholipase activity was greater than in controls, thus demonstrating that enzyme activity was not due to pancreatic phospholipase. Bacterial origin of phospholipase activity was excluded in that phospholipase activity was found in germ-free rats; gastric and salivary gland origins were excluded in that continued phospholipase activity was found in rats with gastric fistula. The physiological importance of the enzyme was established by the finding that rats with pancreatic fistula absorbed $111 \mu \mathrm{mol}$ of phosphatidylcholine and that controls absorbed $119 \mu \mathrm{mol}$ of a $135-\mu \mathrm{mol}$ load. Activity was found to be three times greater in the distal than in the proximal intestine; in cryptal cells it was 10 times greater than in villus tip cells. $65 \%$ of the activity in the gut lumen was tightly bound to particulate matter. We propose that intestinal phospholipase may be important in gut bacterial control, in the digestion of vegetable matter (phosphatidylglycerol is a major phospholipid in both plants and bacteria), and in the digestion of phospholipids in the gut lumen.

This work has been published in part in abstract form (1980. Gastroenterology. 78: 1217) and was presented at the meeting of the American Gastroenterological Association, Salt Lake City, Utah, 19 May 1980.

Received for publication 12 February 1981, and in revised form 13 October 1981.

\section{INTRODUCTION}

Phospholipids are considered to be essential structural components of cellular and intracellular membranes. It is well established that these phospholipids undergo constant metabolic turnover, suggesting the presence of intracellular phospholipases (1). Indeed, phospholipases have been demonstrated in several tissues of various species of animals (1). Although the phospholipases of exocrine secretions, e.g., those of the pancreas (for a review, see de Haas et al. [2]) or of snake venoms (3), have been studied extensively, the physiological functions of intracellular phospholipases are only beginning to be understood (1).

Beginning in 1931, workers in several laboratories (4-16), using endogenous phospholipids, exogenous phosphatidylcholine (PC), ${ }^{1}$ or phosphatidylethanolamine (PE) as substrates, have described phospholipases from the intestinal mucosa. Unfortunately, these investigations were carried out with crude intestinal preparations, and contamination by enzymes from other origins (e.g., the pancreas) cannot be ruled out. Five years ago we reinvestigated this question, using monomolecular films of didodecanoylphosphatidylglycerol $\left(\mathrm{diC}_{12} \mathrm{PG}\right)$ as a phospholipase substrate. Recently, using pig intestinal mucosa, we purified an acid-stable, low-molecular-weight $(16,200)$ phospholipase A that hydrolyzes phosphatidylglycerol (PG) at least 500 times more rapidly than PC (R. Verger et al., manuscript in preparation). We consider this narrow enzymatic substrate specificity, in association with other molecular properties, to be proof of the existence of a new intestinal enzyme different from the wellknown pancreatic phospholipase $\mathrm{A}_{2}$. In the present paper, we report evidence of this intestinal phospholipase in rats and compare its activity in rats with its activity in several other species, including man.

${ }^{1}$ Abbreviations used in this paper: $\operatorname{diC}_{12} \mathrm{PG}$, didodecanoylphosphatidylglycerol; PC, phosphatidylcholine; PE, phosphatidylethanolamine, PG, phosphatidylglycerol. 


\section{METHODS}

\section{Animal procedures}

Nonfasting male Sprague Dawley rats weighing 200-400 $g$ were routinely used. The animals were killed by a blow to the head, and the intestines were quickly removed. The intestines were rinsed in $0.15 \mathrm{M} \mathrm{NaCl}\left(4^{\circ} \mathrm{C}\right)$, divided into quarters from pylorus to cecum, and kept in $0.15 \mathrm{M} \mathrm{NaCl}$ at $4^{\circ} \mathrm{C}$ until scraped. Where indicated, the luminal washings were saved. Two gnotobiotic rats obtained from Centre de Recherche et d'Elevage des Oncins, St. Germain sur l'Arbresle, France, were treated in a similar manner. The lack of an intestinal microflora was confirmed by culturing cecal contents for $48 \mathrm{~h}$ under aerobic conditions at $37^{\circ} \mathrm{C}$. In one of the two rats more extensive bacteriological studies were performed. Three samples from the colon were placed in Schaedler broth with $0.025 \%$ sodium polyanthenol sulfanate and vitamin $K_{3}$ to test for anaerobic growth. Every $48 \mathrm{~h}$ for $8 \mathrm{~d}$, samples were placed in "chocolat Pointelex" broth and triptocase-soy, $5 \%$ sheep-blood broth. No growth was observed under these conditions. Two colonic samples were placed in brain-heart broth with $0.025 \%$ sodium polyanthenol sulfanate to test for aerobic growth. No growth was observed.

Rats in which pancreatic juice was diverted were operated on under ether anesthesia. A tight ligature was placed at the junction of the common bile duct and the duodenum. The common bile duct was cannulated above the ligature, allowing bile to be diverted to the exterior. The animals were placed in a restraining cage and given alimentation fluid (Trophysan or Trophysan Glucidique 50, Laboratoire Egic, Amilly, France) to drink ad lib. for $48 \mathrm{~h}$. This ensured the removal of residual pancreatic enzymes, some of which are known to closely adhere to the intestinal mucosa $(17,18)$. After the 48-h period, the rats were killed, and the intestines were removed as described above. Unoperated control rats were maintained similarly and given the same diet.

Rats in which gastric and pancreatic-biliary secretions were diverted were operated on as described above, except that, in addition, the duodenum was transsected and catheters were placed retrograde into the stomach and antegrade into the proximal duodenum. Both catheters were secured with ligatures and the abdomen was closed. The gastric and common duct catheters were allowed to drain. Trophysan was administered through the duodenal catheter at a rate of $60 \mathrm{ml} / \mathrm{d}$ by a constant-infusion pump (LKB-Produkter $A B$, Stockholm). Because rats operated on in this manner did not tolerate the surgery as well as the rats with the lesser operation, they were killed at $24 \mathrm{~h}$.

The common bile duct of rats in which PC absorption was measured was cannulated, and the common duct was ligated either at its junction with the duodenum (pancreatic juicediverted rats) or $2 \mathrm{~cm}$ proximal to the duodenum (control rats). Three pairs of rats were infused with Vivonex HN (Eaton Laboratories, Norwich, N. Y.) at a rate of $4.5 \mathrm{ml} \mathrm{h}^{-1}$ for $2 \mathrm{~d}$. An infusion of $0.5 \mu \mathrm{Ci}\left[{ }^{14} \mathrm{C}-\mathrm{Me}\right] \mathrm{PC}$ (Amersham Corp, Arlington Heights, Ill.) in $10 \mathrm{mM}$ PC, $20 \mathrm{mM}$ taurocholate (Sigma Chemical Co., St. Louis, Mo.), and Tris buffer (pH 7.0) (Sigma Chemical Co.) in $0.15 \mathrm{M} \mathrm{NaCl}$ was given at a rate of $4.5 \mathrm{ml} \mathrm{h}^{-1}$ for $3 \mathrm{~h}$. The rats were given an overdose of pentobarbitol intraperitoneally, and the gastric contents and cecal contents were separately removed. The intestine was flushed with $0.15 \mathrm{M} \mathrm{NaCl}(15 \mathrm{ml})$, and the contents were collected.

Pig, sheep, and ox intestines were obtained from the local slaughter house. Dog intestine was obtained through the courtesy of Dr. Verine, INSERM, Marseille, France. The dog had received an ileal Thiery-Vella fistula $8 \mathrm{mo}$ previously. At death, samples of duodenum, fistula, and distal ileum were obtained. Cat intestine was obtained from Dr. M. Gonella, Institut de Neurophysiologie, Centre National de la Recherche Scientifique, Marseille, France. Two samples of histologically normal distal duodenal mucosa were obtained through the courtesy of Dr. C. Figarella, Institut National de la Santé et de la Recherche Médicale, Marseille, France.

\section{Enzyme samples}

The intestine was opened on a glass plate on ice, cleaned, and scraped as described previously (19). The resulting mucosa was prepared for analysis by two different procedures. In the first, the mucosa was delipidated by homogenizing sequentially with 2 vol of acetone twice, 3 vol of 9:1 chloroform-butanol thrice, and $2 \mathrm{vol}$ of ethyl ether twice. The resulting dry powder was extracted in $100 \mathrm{vol}$ of $1 \mathrm{~N} \mathrm{HCl}$. The suspension was continuously stirred with a magnetic stirrer in a cold room for $1 \mathrm{~h}$. A clear supernatant was produced by centrifugation at $20,000 \mathrm{~g}$ for $20 \mathrm{~min}$ in a Sorvall RC $2 \mathrm{~B}$ at $4^{\circ} \mathrm{C}$ (DuPont Instruments-Sorvall, DuPont Co., Norwalk, Conn.). In the second, 3 vol of $1 \mathrm{~N} \mathrm{HCl}$ was added, and the mucosa was homogenized. A clear to slightly turbid supernatant was produced by centrifugation in a table-top centrifuge with conical plastic centrifuge tubes (Beckman Instruments, Inc., Palo Alto, Calif.). This method was also employed when rat organ surveys were carried out and when species other than rat were investigated.

To obtain a particulate and a supernatant fraction, other samples of the homogenate were centrifuged first. The particulate fraction was homogenized in $3 \mathrm{vol}$ of $1 \mathrm{~N} \mathrm{HCl}$, and the supernatant fraction was mixed vol:vol with $1 \mathrm{~N} \mathrm{HCl}$. In other studies, the particulate fraction was homogenized twice in $0.15 \mathrm{M} \mathrm{NaCl}$ and finally with $3 \mathrm{vol}$ of $1 \mathrm{~N} \mathrm{HCl}$.

When phospholipase activity was determined in the intestinal luminal fluid, the collected intestinal content was homogenized in $0.15 \mathrm{M} \mathrm{NaCl}$ in a Teflon-glass homogenizer in the cold room.

To localize enzyme content in intestinal cells as it changes along the villus, the method of Weiser (20), as modified by Gratecos et al. (21), was used to differentially release cells from the villus. Aliquots of released cells were collected by centrifugation and separated into two parts. One sample was frozen for subsequent determination of alkaline phosphatase assay, and the other was homogenized with 3 vol of $1 \mathrm{~N} \mathrm{HCl}$ for phospholipase assay.

\section{Enzyme assays}

Phospholipase. All assays, unless otherwise specified, were performed with a three-compartment zero-order trough as previously described (22). The water used was first deionized and then distilled from alkaline permanganate in an allglass still. To this water was added Tris-base, $\mathrm{CaCl}_{2}$, and EDTA at the respective concentrations of 10,100 , and $1 \mathrm{mM}$ and adjusted to $\mathrm{pH} 8.0$ with $\mathrm{HCl}$. This buffer was added to the trough, and the surface was cleansed five times with a pasteur pipette connected to a water aspirator. $\operatorname{diC}_{12} \mathrm{PG}$ (a generous gift of Dr. J. F. Tocanne, Toulouse, France) was added to the surface in a methanol-chloroform (1:5) solution with a 1-ml all-glass syringe to the required surface pressure. Because the surface pressure for optimal enzyme activity was found to be $\sim 20$ dyn $\mathrm{cm}^{-1}$, this pressure was used in all experiments unless otherwise indicated. The temperature 
of all experiments was $23^{\circ} \pm 0.5^{\circ} \mathrm{C}$, which was maintained in a thermostatically controlled metallic box. After a 2-min control period that ensured the absence of spontaneous hydrolysis of substrate, enzyme (25-200 $\mu \mathrm{l})$ was injected into the stirred subphase of the reaction compartment, and the rate of hydrolysis of substrate at constant surface pressure was recorded. For calculating the reaction rate, only the initial linear portion of the curve was used. Reaction rates were stable for at least $5 \mathrm{~min}$. After the lipid covering approximately one-third of the surface of the reservoir had been hydrolyzed, the communication between the first and second reaction compartments was interruped by putting a small Teflon bar across the communication channel. The solution from the first reaction compartment was quickly aspirated, and, after a 2-min control period that ensured that enzyme from the first reaction compartment did not contaminate the second, the procedure was repeated for the second compartment and finally for the third compartment.

Surface pressure $(\pi)$ was measured by the Whilhelmy plate method with a thin platinum plate attached to a Prolabo tensionmeter (Paris, France). The system was automated in our laboratory by $\mathrm{M}$. Bidaud. As hydrolysis in the reaction compartment occurred, product desorbed from the surface and surface pressure fell. Surface pressure was maintained with a surface barostat as described (23). The rate of movement of the barrier was taken as the rate of activity of the enzyme. This value could be converted into nanomoles of substrate hydrolyzed per minute by the following considerations:

First, to determine the area occupied by a single $\operatorname{diC}_{12} \mathrm{PG}$ molecule, a $\pi$ per area curve was constructed with the buffer routinely employed. A known amount of $\mathrm{diC}_{12} \mathrm{PG}$ was added to the surface of the water. Surface pressure was measured as surface area was contracted until film collapse occurred (46 dyn $\mathrm{cm}^{-1}$ ). This determination was performed in triplicate, as was the automated analysis for phosphorus in a measured quantity of the $\mathrm{diC}_{12} \mathrm{PG}$ sample (24). The results agreed closely with those previously presented by Tocanne et al. (25). At each surface pressure, moles of substrate hydrolyzed per minute per milligram of protein was then calculated:

\section{width of trough $(\mathrm{cm}) \times$ rate of movement of barrier $\left(\mathrm{cm} \mathrm{min}^{-1}\right) \times$ molecules $/ \mathrm{cm}^{2}$ Avogadro's number $\left(6.02 \times 10^{23}\right) \times \mathrm{mg}$ of protein}

Because the area of the reaction chamber was $121 \mathrm{~cm}^{2}$, the results of Eq. 1 were divided by 121 to yield the reaction rate per square centimeter of reaction surface.

Where utilized, one arbitrary unit of activity is defined by the hydrolysis of the lipid occupying $4 \mathrm{~cm}^{2}$ of surface area of the reservoir compartment.

It should be noted that, unlike the case in bulk assays, only a small proportion of the enzyme added is actually at the surface of the reaction compartment. It is only this surface-adsorbed enzyme that is active. Preliminary evidence, obtained with ${ }^{125} \mathrm{I}$ labeled purified enzyme from the intestinal lumen, ${ }^{2}$ indicates that only $7.5 \%$ of the enzyme added could actually be localized to the surface at $20 \mathrm{dyn} \mathrm{cm}^{-1}$ by the techniques previously described (22). Therefore, the specific activities from monolayer studies quoted in this paper are probably underestimated by a factor of 13.3 .

Enzyme activity was also determined by the egg yolk assay of de Haas et al. (26). Although this assay is optimized with regard to $\mathrm{Ca}^{2+}$ and bile acid concentration for porcine pancreatic phospholipase, the concentrations of these assay constituents were found to be optimal for the rat as well. The assays were performed with a Radiometer TTT 60 Titrator (Copenhagen, Denmark) and pH stated to 8.00 .

To determine the hydrolytic site specificity of the mucosal enzyme, mucosa (villus tips discarded) from the distal one-half intestine from a rat in which the pancreatic juice had been diverted for $48 \mathrm{~h}$ was delipidated, and the enzyme was extracted with $20 \mathrm{vol}$ (wt/vol) $1 \mathrm{~N} \mathrm{HCl}$. 0.1-0.2 ml of enzyme was incubated for 5 and $20 \mathrm{~min}$ at $37^{\circ} \mathrm{C}$ with $0.48-0.58 \mathrm{ml}$ of $0.15 \mathrm{M}$ $\mathrm{NaCl}, 6 \mu \mathrm{mol}$ of $\mathrm{CaCl}_{2},\left[s n-1-{ }^{3} \mathrm{H}, s n-2-{ }^{14} \mathrm{C}\right] \mathrm{PG}\left({ }^{3} \mathrm{H}, 3.0 \times 10^{4}\right.$ cpm and ${ }^{14} \mathrm{C}, 9.4 \times 10^{3} \mathrm{cpm}$ ), and $40 \mu \mathrm{mol}$ of Tris- $\mathrm{HCl}$ in a total volume of $1.1 \mathrm{ml}$. The incubation mixture was titrated to $\mathrm{pH}$ 7.84 with $1 \mathrm{~N} \mathrm{NaOH}$. At the end of the incubation, the lipids were extracted, and the radioactivity of the fatty acids released was differentially measured after thin-layer chromatography of the lipid extract (silica gel G layers: hexanes/ether/methanol/ acetic acid, 80:20:9:2, vol/vol). Incubations were also performed with phospholipase $A_{2}$ from Russell viper venom (Sigma Chem-

\footnotetext{
${ }^{2}$ Verger, R., G. Pieroni, C. Mansbach, and F. Ferrato. Submitted for publication.
}

ical Co.) and without enzyme addition to test for spontaneous release of fatty acid.

Alkaline phosphatase. Alkaline phosphatase was used to identify the level of released intestinal villus cells. The assay used was that described by Louvard et al. (27) and was thermostated to $37^{\circ} \mathrm{C}$. Absorbance at $410 \mathrm{~nm}$ was followed in a Unicam SP 1700 Spectrometer equipped with a Unicam AR 25 Recorder (Philips Science et Industrie, Paris).

Chymotrypsin. Chymotrypsin was used to test the efficacy of the exclusion of pancreatic juice from the intestine and was assayed according to the method of Louvard and Puigserver (28). Acetyl-L-tyrosine ethyl ester was used as substrate.

\section{Chemical analysis}

Protein was measured by the method of Lowry et al. (29). Lipids were extracted by the method of Folch et al. (30). PC and lyso-PC were isolated by thin-layer chromatography (31) and quantitated (32).

\section{Radioactivity}

A Packard model 3390 Liquid Scintillation Spectrometer (Packard Instrument Co., Inc., Downers Grove, Ill.) was used to determine the radioactivity of appropriate samples.

\section{Chemicals}

PC was isolated from eggs as previously described (31). $\left[{ }^{3} \mathrm{H},{ }^{14} \mathrm{C}\right] \mathrm{PG}$ was synthesized from $s n-1-\left[{ }^{3} \mathrm{H}\right]$ palmitoyl, $s n-2-$ $\left[{ }^{14} \mathrm{C}\right]$ linoleoyl $\mathrm{PE}$ by transesterifying the PE with glycerol (33). The PE, a generous gift of Dr. Mosley Waite, Bowman Gray School of Medicine, Winston-Salem, N. C., was reacted with $80 \mu \mathrm{mol}$ of sodium acetate, $40 \mu \mathrm{mol}$ of $\mathrm{CaCl}_{2}, 20 \%$ vol:vol glycerol, and $0.1 \mathrm{ml}$ of phospholipase $\mathrm{D}$ in a final volume of $0.6 \mathrm{ml} .0 .5 \mathrm{ml}$ of ethyl ether, washed three times with water, was added, and the reaction mixture was placed on a Vortex mixer (Scientific Industries, Springfield, Mass.) at room temperature for $20 \mathrm{~min}$. The reaction was stopped by adding $0.1 \mathrm{ml}$ of $1 \mathrm{~N} \mathrm{HCl}$, and the lipids were extracted with ethyl ether/ethanol 4:1 ( $\mathrm{vol} / \mathrm{vol})$. The ether phase was 
aspirated and dried under $\mathrm{N}_{2}$, and PG was isolated by thinlayer chromatography (34). Phospholipase D was partially purified (through stage 3) from Savoy cabbage (35).

\section{RESULTS}

Because no mucosal phospholipolytic activity was demonstrable by the classic egg yolk assay, PG was investigated and found to be a suitable substrate. However, PG precipitates from solution at the concentrations of $\mathrm{Ca}^{2+}$ required for optimum enzyme activity. Therefore, the surface barostat technique had to be employed.

As shown in Table I, there is high phospholipase specific activity present in intestinal mucosa. In contrast to previous reports of enzymes associated with the digestion of dietary substrates (36), phospholipase specific activity in intestinal mucosa was found to increase with increasing distance from the pylorus.

With $\mathrm{diC}_{12} \mathrm{PG}$ as substrate, phospholipase activity was found in the intestinal luminal contents, $117 \pm 3$ $\mathrm{nmol} \min ^{-1} \mathrm{mg}$ protein ${ }^{-1}$. This value is close to the average mucosal specific activity and suggests that the luminal activity could have been secreted by the intestinal mucosa. With $\mathrm{diC}_{12} \mathrm{PG}$ as substrate, the total amount of activity present in the intestinal contents was also found to be quite large, $6.2 \pm 1.1 \mu \mathrm{mol} \mathrm{min}{ }^{-1}$. It was also of interest to determine whether the enzyme was bound to particulate matter in the intestinal content. $65 \%$ of the activity was found to be bound to easily centrifugable particulate contents. Only $5 \%$ of this activity could be removed by resuspending the sediment in $0.15 \mathrm{M} \mathrm{NaCl}$. Thus, the binding of phospholipase activity to luminal particulate matter was assumed to be tight.

The activity in the intestinal lumen could well have come from pancreatic phospholipase $A_{2}$. This possi-

TABLE I

Specific Activity of Intestinal Phospholipase in Rat Mucosa

\begin{tabular}{lcccc}
\hline & \multicolumn{5}{c}{ Gut segment• } \\
\cline { 2 - 5 } & 1 & 2 & 3 & 4 \\
\hline Specific activity $!$ & $62 \pm 9$ & $118 \pm 22$ & $143 \pm 26$ & $185 \pm 33$ \\
Univariate $P$ values $\$$ & 0.0092 & 0.2365 & 0.6082 & \\
Multivariate $P$ value & $P<0.0078$ & & & \\
\hline
\end{tabular}

- Each quarter of the intestine, pylorus to cecum.

$\downarrow$ Nanomoles per minute per milligram of protein.

The univariate $P$ values compare each quarter of the intestine with segment 4.

"The multivariate $\boldsymbol{P}$ value tests the null hypothesis that enzyme activity from each gut segment is derived from a single population. Performed on an IBM 1130 Computer (IBM Corp., Armonk, N. Y.) bility was enhanced by the finding that, unlike the phospholipase activity extractable from the mucosa, the luminal enzyme was active in the egg yolk assay

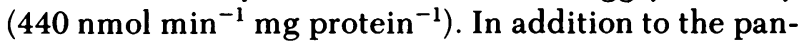
creas, however, several other possible sources for the activity in the intestinal lumen and in the mucosa were considered. The enzyme could have come from the gastric mucosa (see below) or from bacteria within the intestinal lumen. These possibilities were ruled out as follows.

A pancreatic derivation of the enzyme was considered the most likely alternative. To rule out this possibility, three rats had their pancreatic juice diverted from the intestine. Chymotryptic activity in the intestinal fluid averaged only $0.63 \pm 0.32 \%$ of the activity observed in controls. By contrast, the total phospholipase activity in the intestinal lumen, as judged by hydrolysis of $\mathrm{diC}_{12} \mathrm{PG}$, was $7.8 \pm 1.4 \mu \mathrm{mol} \mathrm{min} \mathrm{m}^{-1} \mathrm{com}$ pared with $6.2 \pm 1.1 \mu \mathrm{mol} \mathrm{min}^{-1}$ in normal rats. The specific activity with egg yolk as substrate was 600 $\mathrm{nmol} \mathrm{min}^{-1} \mathrm{mg}$ protein ${ }^{-1}$ (one determination) compared with $440 \mathrm{nmol} \mathrm{\textrm {min } ^ { - 1 }} \mathrm{mg}$ protein ${ }^{-1}$ in normal rats. $65 \%$ of the activity with $\mathrm{diC}_{12} \mathrm{PG}$ as substrate was bound to particulate matter, as was seen in the intact rat. Enzyme activity was also determined in the intestinal mucosa of two pancreatic juice-diverted rats. The averaged phospholipase specific activity $\left(\mathrm{diC}_{12} \mathrm{PG}\right.$ as substrate) in the intestinal mucosa in each quarter of the intestine was greater than in normal rats 199 ,

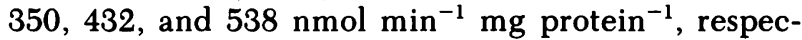
tively. Thus, it is highly unlikely that the phospholipase activity in the mucosa or in the intestinal lumen was of pancreatic origin.

Next, it was considered possible that the phospholipase activity was of bacterial origin. However, the two germ-free rats demonstrated phospholipolysis $\left(\mathrm{diC}_{12} \mathrm{PG}\right.$ as substrate) in the mucosa of each quarter of the intestine $\left(245,414,441\right.$, and $518 \mathrm{nmol} \mathrm{min}{ }^{-1}$, respectively) at the same level as normal rats $(220,329$,

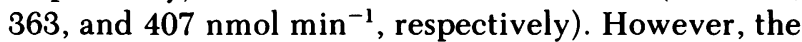
total amount of activity in the intestinal lumen with $\operatorname{diC}_{12} \mathrm{PG}$ as substrate was somewhat reduced in these rats $\left(1.4 \mu \mathrm{mol} \mathrm{min}^{-1}\right)$ as compared with controls $\left(6.2 \pm 1.1 \mu \mathrm{mol} \mathrm{min}^{-1}\right)$, although the specific activity remained high, $407 \mathrm{nmol} \mathrm{\textrm {min } ^ { - 1 } \mathrm { mg } \text { protein }}{ }^{-1} \mathrm{com}$ -

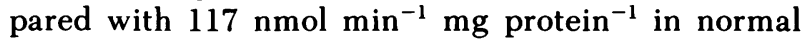
rats. The reduction in total activity was assumed to be due to reduced content of particulate matter in the intestinal lumen of these gnotobiotic rats. The intestinal contents of one gnotobiotic rat were tested at a surface pressure of $10 \mathrm{dyn} \mathrm{cm}^{-1}$ in the surface barostat with $\mathrm{diC}_{12} \mathrm{PC}$ as substrate. The activity, $382 \mathrm{nmol}$ $\mathrm{min}^{-1} \mathrm{mg}$ protein ${ }^{-1}$, was similar to that found in normal rats by the egg yolk assay $\left(440 \mathrm{nmol} \mathrm{min}^{-1} \mathrm{mg}\right.$ protein $\left.^{-1}\right)$. These data suggest that the phospholipase 
activity observed in normal rats was not of bacterial origin.

Lastly, it was theorized that the phospholipase activity could be of gastric or salivary gland origin. To rule out this possibility, two rats with gastric and duodenal fistulae and pancreatic juice diversion were studied. Pancreatic juice was successfully diverted, as judged by chymotryptic activity that was $1 \%$ of control values, despite the shortened length of time of fistulation $(25 \mathrm{~h})$. Specific activity $\left(\mathrm{diC}_{12} \mathrm{PG}\right.$ as substrate) in the intestinal lumen remained high, $84 \mathrm{nmol} \mathrm{min}^{-1}$ mg protein ${ }^{-1}$ compared with $117 \mu \mathrm{mol} \mathrm{min}^{-1} \mathrm{mg}$ protein $^{-1}$ in normal rats, despite diversion of gastric, salivary gland, and pancreatic secretions from the intestinal tract.

Taken together, these data suggest that the phospholipase activity observed in the intestinal lumen and in the intestinal mucosa was of intestinal mucosal origin. The data do not establish that they are the same enzyme, because the luminal enzyme differs significantly from the mucosal enzyme in that it is active in the egg yolk assay, whereas the mucosal enzyme is not.

Because luminal phospholipase activity continued high, despite pancreatic juice diversion, we considered it important to test whether pancreatic juice-diverted rats could absorb physiologically important amounts of PC. $7.8 \mathrm{mM} \mathrm{PC}$ containing $\left[{ }^{14} \mathrm{C} \mathrm{Me}\right] \mathrm{PC}$ was infused for $3 \mathrm{~h}$ at $4.5 \mathrm{ml} \mathrm{h}^{-1}$. Because $<1 \%$ of the counts per minute infused were found in the stomach and cecum, the percent PC absorbed was calculated on the basis of the number of counts per minute infused as compared with the number of counts per minute recovered from the lumen in the lyso-PC and PC fractions. By this method, $84 \pm 4$ and $87 \pm 5 \%$ of the infused $P C$ was absorbed in the control and pancreatic juice-diverted rats, respectively. Thus, as judged by infusate PC specific activity, control rats absorbed $88 \mu \mathrm{mol}$ and diverted rats $92 \mu \mathrm{mol}$ of PC during the $3-\mathrm{h}$ infusion period. These data were confirmed when the mass of PC infused was compared with the mass of PC and lyso-PC remaining in the intestinal lumen at the end of the infusion. When the amount absorbed was calculated on the basis of mass, $86 \pm 5$ and $91 \pm 6 \mu \mathrm{mol}$ of PC were absorbed in the control and pancreatic ductdiverted rats, respectively. The percent of counts per minute recovered from the intestinal lumen present as lyso-PC was also the same in both groups, $29 \pm 0.5$ and $30 \pm 3 \%$ in the control and pancreatic juice-diverted groups, respectively. In summary, the pancreatic juice-diverted rat was able to normally hydrolyze and absorb PC, despite the lack of pancreatic phospholipase.

We next studied the possibility of a villus site of origin of the phospholipase activity. As shown in Fig. 1 , cells were successively fractionally released from villus tip to crypt, as judged by the progressive re- duction in alkaline phosphatase activity, as previously described $(20,21)$. The specific activity of alkaline phosphatase was 42 times higher in villus tip cells than in cryptal cells in the proximal intestine and 81 times higher than in cryptal cells in the distal intestine. By contrast, as shown in the figure, the specific activity of intestinal phospholipase was significantly increased in cryptal cells vs. mature villus tip cells. This suggests that the synthesis of intestinal phospholipase is 7-12 times more active in cryptal cells as compared with villus tip cells. Because of this finding, we considered it possible that the phospholipase activity originated in Paneth cell granules. This possibility was ruled out by the finding that there was no phospholipase activity in a preparation of Paneth cell granules (kindly donated by Dr. D. Balas, Toulouse, France).

Because phospholipases hydrolyze various parts of phospholipids, we considered it important to establish which ester bond was attacked by the mucosal enzyme. Enzyme was prepared from a rat in which the pancreatic juice had been diverted for $48 \mathrm{~h}$ and incubated with $s n-1-\left[{ }^{3} \mathrm{H}\right]$ palmitoyl, $s n-2-\left[{ }^{14} \mathrm{C}\right]$ linoleoyl PG. The ${ }^{3} \mathrm{H} /{ }^{14} \mathrm{C}$ ratio of released fatty acids was 6.6:1, which should be compared with a ratio of $0.3: 1 \mathrm{ob}-$

LOCALIZATION OF IMTESTIMAL PHOSPHOLIPASE alOMG the VILLUS

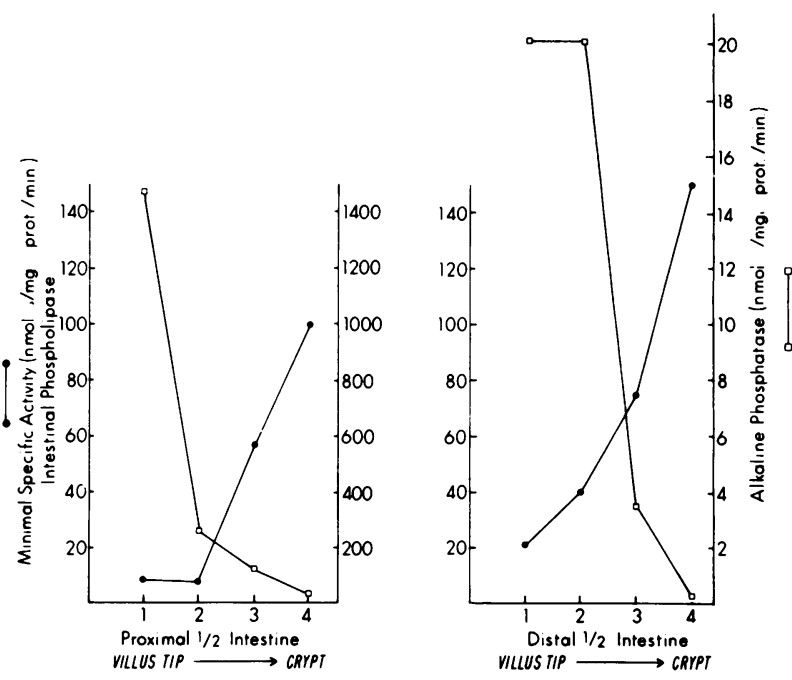

FIGURE 1 The distribution of intestinal phospholipase activity along the crypt-villus complex from the proximal (left) and distal (right) one-half intestine. Cells were progressively released from the villus as described in Methods. The released cells were combined into four separate fractions as indicated on the abscissa. Phospholipolytic activity $\left(\operatorname{diC}_{12} \mathrm{PG}\right.$ as substrate) was determined on $1 \mathrm{~N} \mathrm{HCl}$ extracts (Methods) and is shown by reference to the left ordinate in both panels. Alkaline phosphatase activity was used to confirm the depth of the released cells and is shown by reference to the right ordinate of both panels. Alkaline phosphatase activity was considerably reduced in the distal one-half intestine as compared with the proximal one-half, in agreement with Kwong et al. (69). Prot., protein. 
TABLE II

Survey of Various Organs in Rat for Phospholipase Activity ${ }^{\circ}$

\begin{tabular}{lc}
\hline \multicolumn{1}{c}{ Organ } & Specific activity \\
& $\begin{array}{c}n m \text { min }^{-1} \\
m \text { prot }^{-1}\end{array}$ \\
Intestine, mucosa $\$ & 127 \\
Stomach, mucosa & 23 \\
Colon, mucosa & 21 \\
Serum & 9 \\
Lung & 0 \\
Kidney & 0 \\
Liver & 0 \\
Heart & 0 \\
Muscle, striated & 0 \\
Adipose tissue & 0 \\
Spleen & 0 \\
\hline
\end{tabular}

- The substrate utilized was $\operatorname{diC}_{12} \mathrm{PG}$, assayed at a surface pressure of 20 dyn $\mathrm{cm}^{-1}$.

$\downarrow$ Average value.

tained with Russell viper venom phospholipase $A_{2}$. Because the ${ }^{3} \mathrm{H} /{ }^{14} \mathrm{C}$ ratio of the original PG was $3.2: 1$, this indicates considerable (12-fold) enrichment of the released fatty acids by ${ }^{14} \mathrm{C}$ as expected for the venom phospholipase $\mathrm{A}_{2}$ and a modest (twofold) enrichment of ${ }^{3} \mathrm{H}$ by intestinal phospholipase. The results establish that the muscosal enzyme is a phospholipase $A$, because of its release of fatty acids. The results further suggest that the enzyme is of the $A_{1}$ type because of its preferential release of the fatty acid esterified at the $s n-1$ position of PG. However, we emphasize that the preparation used was impure and that final assignment of the enzyme's substrate specificity awaits similar studies with pure enzyme. $6 \%$ of the ${ }^{3} \mathrm{H}$ and no ${ }^{14} \mathrm{C}$ were released spontaneously from PG incubated without enzyme.

Although phospholipase activity has been demonstrated in the intestine with $\mathrm{diC}_{12} \mathrm{PG}$ as substrate, phospholipases have also been reported in many other tissues. For this reason, a tissue survey was undertaken in the rat to determine the uniqueness of this enzymatic activity. As can be seen in Table II, serum, gastric mucosa, and colonic mucosa demonstrated activity. Pancreas was not assayed, since purified porcine pancreatic phospholipase $A_{2}$ is quite active against $\mathrm{C}_{12} \mathrm{PG} .{ }^{3}$ Plasma activity was $75 \%$ less than that of serum, which was not due to heparin, because the addition of heparin to serum did not reduce its activity (10 $\mathrm{nmol} \mathrm{min} \mathrm{ml}^{-1} \mathrm{ml}^{-1}$ serum vs. $9.44 \mathrm{nmol} \mathrm{min}{ }^{-1} \mathrm{ml}^{-1}$ upon the addition of heparin 1:5). The location of ac-

\footnotetext{
${ }^{3}$ Pieroni, G., C. Mansbach, F. Ferrato, and R. Verger. Submitted for publication.
}

tivity was further investigated by bringing the serum to a density of 1.21 with $\mathrm{KBr}$ and centrifuging it at $45,000 \mathrm{rpm}$ in a SW 50.1 rotor (Beckman Instruments Co., Inc.) for $24 \mathrm{~h}$. The resulting serum was fractionated by piercing the bottom of the tubes. $96 \%$ of the activity was recovered, of which $59 \%$ was in the heaviest fraction. No activity was found in the lipoproteincontaining fractions at the top of the tube. The presence of activity in serum was peculiar to rat, since it was not found in pig or human samples.

A variety of species was assayed for activity in the intestine, and the results are presented in Table III. Activity was low or nonexistent in carnivorous species, whereas activity was present in omnivorous and herbivorous species.

\section{DISCUSSION}

Tissue surveys for phospholipase have consistently revealed enzymatic activity in the intestine (4-16). However, it is doubtful that the enzyme described in the present report is the same as those that have been described by past investigations. There are three reasons for this. Firstly and most importantly, the enzyme isolated from the intestinal mucosa described herein is not active against PC as substrate, neither in the egg yolk assay nor when injected beneath a monolayer of $\mathrm{diC}_{12} \mathrm{PC}$ at different surface pressures (10-25 dyn/ $\mathrm{cm})$. Secondly, the level of activity we observed when $\operatorname{diC}_{12} \mathrm{PG}$ was used as substrate is considerably greater than previously reported phospholipase activities as determined by other assay systems. Lastly, in two stud-

TABLE III

Intestinal Mucosal Phospholipase: Activity in Various Animal Species ${ }^{\circ}$

\begin{tabular}{lcc}
\hline \multicolumn{1}{c}{ Animal species } & Duodenum & Ileum \\
\hline & \multicolumn{2}{c}{$n$ mol min $^{-1}$ mg protein $^{-1}$} \\
Rat $(n=5)$ & $62 \pm 11 \downarrow$ & $185 \pm 33 \ddagger$ \\
Pig $(n=2$ & 67 & 153 \\
Dog $(n=1) \S$ & 14 & 0 \\
Cat $(n=2)$ & NA" & 0 \\
Man $(n=2)$ & 670 & NA" \\
Sheep $(n=4)$ & $80 \pm 13$ & $110 \pm 77$ \\
Ox $(n=1)$ & 140 & 150 \\
\hline
\end{tabular}

- $\mathrm{diC}_{12} \mathrm{PG}$ was used as substrate at a surface pressure of 20 dyn $\mathbf{c m}^{-1}$.

$\downarrow$ Mean \pm SEM for $n>4$ or average when $n=2$.

"Not available.

- Duodenal biopsies obtained for diagnostic purposes were histologically normal.

\$ No activity was found in the Thiery-Vella loop (made from ileum) or in secretions from the loop. The activity reported in the table is from ileum distal to the loop. 
ies $(7,8)$ the phospholipase was acid precipitable, whereas the enzyme presented here is clearly acid soluble.

In general, phospholipases can be divided into two groups on the basis of specific activity. The phospholipases of the first group, whose specific activity is in the range of $1 \times 10^{-9} \mathrm{~mol} \mathrm{~min}^{-1} \mathrm{mg}$ protein ${ }^{-1}$, are often membrane bound and do not always require $\mathrm{Ca}^{2+}$ for activity (37-50). The second group of phospholipases, with specific activities that exceed $1 \times 10^{-6} \mathrm{~mol}$ $\min ^{-1} \mathrm{mg}$ protein ${ }^{-1}$, require $\mathrm{Ca}^{2+}$ for activity, are of low molecular weight $(\sim 14,000)$, and are soluble and acid-stable proteins that are secreted from their cell of origin (51-58). The enzyme described in the present study, when partially purified from porcine intestinal mucosa, is small, has a specific activity of $25 \times 10^{-6}$ mol $\min ^{-1} \mathrm{mg}$ protein ${ }^{-1}$, requires $\mathrm{Ca}^{2+}$ for activity, and is acid stable, clearly placing it in the group of phospholipases that are secreted.

The total activity in the intestinal lumen of the pancreatic juice-diverted rat, $37 \mu \mathrm{mol}$ PC hydrolyzed $\min ^{-1}$ as determined by the egg yolk assay, clearly is enough to hydrolyze all the PC delivered to the intestine each day (59). Thus, rats should be able to, and have been demonstrated in this study to, absorb physiologically important amounts of PC, despite the absence of pancreatic juice in the intestine. The relevance of this data assumes that PC must be hydrolyzed before its absorption (60). This intestinal enzyme might also explain the persistance of phospholipase activity (PC as substrate) in the lumen of the distal intestine at a level similar to that found in the proximal intestine, in contrast to other pancreatic enzymes (61). Indeed, Arnesjo et al. (61) suggested the possibility of a phospholipase other than pancreatic phospholipase to explain their findings.

What kind of a physiologic role could be envisaged for such an enzyme? In several cell systems, most notably the platelet system, phospholipase activity is related to providing arachidonic acid for prostaglandin synthesis (1). Clearly, prostaglandins have effects on the intestine, and a local site of its synthesis is reasonable to expect. However, the quantity of enzyme present in the tissue, $16 \mu \mathrm{g} / \mathrm{g}$ wet wt, is considerably greater than would be expected for this purpose alone.

Another possibility is a digestive function. Clearly, this would be in addition to pancreatic phospholipase $\mathrm{A}_{2}$. However, like most proteins, the pancreatic phospholipase is subject to degradation by the proteolytic enzymes within the intestinal lumen (62). Therefore, during digestive periods, PC or PG not hydrolyzed by pancreatic phospholipase $A_{2}$ could be hydrolyzed by the secreted intestinal enzyme, and, during interdigestive periods, when pancreatic phospholipase $\mathrm{A}_{2}$ concentrations would be expected to be low, PC entering the lumen could be digested by intestinal phospholi- pase. Considerable amounts of PC enter the lumen from sloughed cells during all hours of the day. Approximately $8 \mu \mathrm{mol}$ of PC could be expected to enter the intestinal lumen via this route each day in the rat, assuming a cell $t_{1 / 2}$ of $48 \mathrm{~h}$ (32). This PC would otherwise be lost to the organism.

Lastly, an intestinal phospholipase active against PG suggests two prime substrates, bacteria and plants, since these are high in PG content. In terms of bacteria, potential hydrolysis could occur either intraluminally or intracellularly. If one considers intraluminal hydrolysis of bacteria first, it is obvious that the small bowel is not sterile, and, therefore, by definition, the enzyme is not completely capable on its own of hydrolyzing all living bacteria. As shown in Table III, carnivores have low intestinal phospholipase activity compared with herbivores and omnivores. Since the bacterial population in the carnivore's intestine is lower than that in plant-eating animals (63), intestinal phospholipase could be related to the number of bacteria free in the intestinal lumen. By contrast, luminal bacteria provide a great part of the nutrition of herbivores. However, the pancreatic phospholipase of horse, ox, and sheep is less "penetrating" than that of the pig, that is, it is not able to hydrolyze substrate at a surface pressure as high as that of the porcine enzyme $(64,65)$. Therefore, in the case of the herbivora, intestinal phospholipase may play an important digestive role, since its penetrability ${ }^{4}$ could enable bacterial digestion. The higher enzyme levels noted in the herbivora also suggest a role for the enzyme in digesting plant PG, but this is unexplored.

The bacteria digested by the intestinal phospholipase does not necessarily have to be within the intestinal lumen. Some bacteria characteristically invade the intestinal mucosa as part of their pathologic process. Clearly, this enzyme could be involved in host defense mechanisms. When bacteria invade the intestinal mucosa from the lamina propria, such as has been postulated to occur in Whipple's disease (66), the bacteria in the mucosal cells have been noted to be undergoing degenerative changes.

Although it is not conclusively proven that the luminal enzyme is the same as the intestinal one, it is highly likely, because sources other than the intestinal mucosa (stomach, salivary gland, bacteria, and pancreas) have been eliminated. Final proof would require in vitro conversion of the mucosal enzyme that lacks activity against PC to the luminal enzyme that hydrolyzes PC. Thus, the mucosal enzyme is viewed as a zymogen in terms of its substrate specificity. However, the analogy with the pancreas is not strict, since treatment of the mucosal enzyme with trypsin, which

\footnotetext{
${ }^{4}$ Pieroni, G., C. Mansbach, F. Ferrato, and R. Verger. Manuscript in preparation.
} 
activates pancreatic prophospholipase $A_{2}(67)$, causes loss of activity against PG with no appearance of activity against PC. In any event, trypsin would not be expected to be the activator in the case of the mucosal enzyme, because the pancreatic juice-diverted rat, with no luminal tryptic activity, retains its ability to hydrolyze PC.

Comparison of the mucosal enzyme reported here and a phospholipase $A_{1}$ isolated from the pancreas (68) suggest that they likely are different enzymes. The intestinal mucosal enzyme requires $\mathrm{Ca}^{2+}$ for activity, whereas the pancreatic enzyme works even in the presence of EDTA. Furthermore, the evidence that the mucosal enzyme is a phospholipase $A_{1}$ further distinguishes it from the major phospholipase secreted by the pancreas, which is a phospholipase $A_{2}(65,67)$.

\section{ACKNOWLEDGMENTS}

The authors thank F. Ferrato and Mary Cox for their expert technical assistance. We also thank Dr. C. Lazdunski (Centre National de la Recherche Scientifique, Marseille) and Dr. D. Lairon (Institut National de la Santé et de la Recherche Médicale, Marseille) for the use of some of their laboratory equipment.

Dr. C. M. Mansbach was supported, in part, by an international fellowship from the Institut National de la Santé et de la Recherche Médicale. Support was also provided by the Medical Research Service of the Veterans Administration and grant AM 27231 from the National Institute of Arthritis, Metabolic, and Digestive Diseases.

\section{REFERENCES}

1. van den Bosch, H. 1980. Intracellular phospholipases A. Biochim. Biophys. Acta. 604: 191-246.

2. de Haas, G. H., A. J. Slotboom, H. M. Verheij, E. H. Jansen, J. M. de-Aroujo, and J. C. Vidal. 1978. Interaction of phospholipase $A_{2}$ with lipid-water interfaces. Adv. Prostoglandin Thromboxane Res. 3: 11-21.

3. Tu, A. T.: Venoms: Chemistry and Molecular Biology. 1977. John Wiley \& Sons, Inc., New York.

4. King, E. J. 1931. The enzymatic hydrolysis of lecithin. Biochem. J. 25: 799-811.

5. Epstein, B., and B. Shapiro. 1957. Intestinal lecithinase. Nature (Lond.). 180: 387.

6. Schmidt, G., M. J. Bessman, and S. J. Thannhauser. 1957. Enzymatic hydrolysis of ceplalin in rat intestinal mucosa. Biochim. Biophys. Acta. 23: 127-138.

7. Epstein, B., and B. Shapiro. 1959. Lecithinase and lysolecithinase of intestinal mucosa. Biochem. J. 71: 615619.

8. Ottolenghi, A. 1964. Estimation and subcellular distribution of lecithinase activity in rat intestinal mucosa. $J$. Lipid Res. 5: 532-537.

9. Gallai-Hatchard, J. J., and R. H. S. Thompson. 1965. Phospholipase A activity of mammalian tissues. Biochim. Biophys. Acta. 98: 128-136.

10. Ottolenghi, A. 1967. Phospholipase activity in rat tissues and its modification by trypsin. Lipids. 2: 303-307.

11. Sarzala, M. G. 1969. Endogenous lipolysis in mitochondria and microsomes from intestinal mucosa and liver. Bull. Acad. Pol. Sci. Ser. Sci. Biol. 17: 285-290.

12. Subbaiah, P. V., and J. Ganguly. 1970. Studies on the phospholipases of rat intestinal mucosa. Biochem. J. 118: 233-239.

13. Bonnefis, M. J., J. Lloveras, and L. Douste-Blazy. 1975. Spécificité d'action des phospholipases de la muqueuse intestinale du rat. C. R. Acad. Sci. (Paris). 280: 661-664.

14. Bonnefis, M. J., G. Rey, J.-P. Thouvenot, and L. DousteBlazy. 1977. Phospholipases de l'intestin de rat: mode d'action. Biochemie. 59: 355-361.

15. Bonnefis, M. J., J. Marmouyet, G. Rey, J-P. Thouvenot, and L. Douste-Blazy: 1960. Influence des lipides de la mugueuse intestinale de rat sur son activité phospholipasique. Biochemie. 60: 521-524.

16. Takigo, R., and T. Sasaki. 1979. Phospholipid-deacylating enzymes of rat small intestinal mucosa. J. Biol. Chem. 85: 29-39.

17. Alpers, D. H., and M. Solin. 1970. The characterization of rat intestinal amylase. Gastroenterology. 58: 833-842.

18. Alpers, D. H., and K. J. Isselbacher. 1967. Protein synthesis by rat intestinal mucosa. J. Biol. Chem. 242: 56175622 .

19. Mansbach, C. M., II. 1973. Complex lipid synthesis in hamster intestine. Biochim. Biophys. Acta. 296: 386400.

20. Weiser, M. M. 1973. Intestinal epithelial cell surface membrane glycoprotein synthesis. J. Biol. Chem. 248: 2536-2541.

21. Gratecos, D., M. Knibiehler, V. Benoit, and M. Sémériva. 1978. Plasma membranes from rat intestine epithelial cells at different stages of maturation. Biochim. Biophys. Acta. 512: 508-524.

22. Rietsch, J., F. Pattus, P. Desnuelle, and R. Verger. 1977. Further studies of mode of action of lipolytic enzyme. J. Biol. Chem. 254: 10090-10094.

23. Verger, R., and G. H. de Haas. 1973. Enzyme reactions in a membrane model. 1. A new technique to study enzyme reactions in monolayers. Chem. Phys. Lipids. 10: 127-136.

24. Amic, J., D. Lairon, and J. C. Hauton. 1972. Technique de dosage automatique de l'orthophosphate de grande fiabilite. Clin. Chim. Acta. 40: 107-114.

25. Tocanne, J. F., P. H. J. Th. Ververgaert, A. J. Verkleij, and L. L. M. van Deenen. 1974. A monolayer and freezeetching study of charged phospholipids. I. Effects of ions and $\mathrm{pH}$ on the ionic properties of phosphatidylglycerol and lysylphosphatidylglycerol. Chem. Phys. Lipids 12: 201-219.

26. Nieuwenhuizen, W., H. Kunze, and G. H. de Haas. 1974. Methods Enzymol. 32B: 147-154.

27. Louvard, D., S. Maroux, J. Baratti, P. Desnuelle, and S. Mutaftschiev. 1973. On the preparation and some properties of closed membrane vesicles from hog duodenal and jejunal brush border. Biochim. Biophys. Acta. 291: 747-763.

28. Louvard, M. N., and A. Puigserver. 1974. On bovine and porcine anionic trypsinogens. Biochim. Biophys. Acta. 371: $177-185$.

29. Lowry, O. H., N. J. Rosenbrough, A. Farr, and R. J. Randall. 1951. Protein measurement with the Folin phenol reagent. J. Biol. Chem. 193: 265-275.

30. Folch, J., M. Lees, and G. H. SloanStanley. 1957. A simple method for the isolation and purification of total lipids from animal tissues. J. Biol. Chem. 226: 497-509.

31. Mansbach, C. M., II. 1977. The origin of chylomicron phosphatidylcholine in the rat. J. Clin. Invest. 60: 411420.

32. Mansbach, C. M., II, and S. Parthasarathy. 1979. Regulation of de novo phosphatidylcholine synthesis in rat intestine. J. Biol. Chem. 254: 9688-9694. 
33. Yang, S. F., S. Freer, and A. A. Benson. 1967. Transphosphatidylation by phospholipase D. J. Biol. Chem. 242: 477-484.

34. Skipski, V. P., M. Barclay, E. S. Reichman, and J. J. Good. 1967. Separation of acidic phospholipids by onedimensional thin layer chromatography. Biochim. Biophys. Acta. 137: 80-89.

35. Davidson, F. M., and C. Long. 1958. The structure of the naturally occurring phosphoglycerides. Action of cabbage-leaf phospholipase $\mathrm{D}$ on ovolecithin and related substances. Biochem. J. 69: 458-466.

36. Harrison, D. D., and H. L. Webster. 1971. Proximal to distal variations in enzymes of the rat intestine. Biochim. Biophys. Acta. 244: 432-436.

37. Waite, M., and P. Sisson. 1971. Partial purification and characterization of phospholipase $A_{2}$ from rat liver mitochondria. Biochemistry. 10: 2377-2383.

38. Newkirk, J. D., and M. Waite. 1973. Phospholipid hydrolysis by phospholipases $A_{1}$ and $A_{2}$ on plasma membranes and microsomes of rat liver. Biochim. Biophys. Acta. 298:562-576.

39. Victoria, E. J., L. M. G. van Golde, K. Y. Hostetler, G. L. Scherphof, and L. L. M. van Deenen. 1971. Some studies in the metabolism of phospholipids in plasma membranes from rat liver. Biochim. Biophys. Acta. 239: 443-457.

40. Rahman, Y. E., J. Verhagen, and D. T. M. van den Wiel. 1970. Evidence of a membrane bound phospholipase A in rat liver lysosomes. Biochem. Biophys. Res. Commun. 38: $670-677$.

41. Nachbaur, J., A. Colbean, and P. M. Vignais. 1972. Distribution of membrane-confined phospholipases $A$ in the rat hepatocyte. Biochim. Biophys. Acta. 274: 426-446.

42. van Golde, L. M. G., B. Fleischer, and S. Fleischer. 1971. Some studies on the metabolism of phospholipids in Golgi complex from bovine and rat liver in comparison to other subcellular fractions. Biochim. Biophys. Acta. 249: 318-330.

43. Gorracci, G., G. Porcellati, and H. Woehl. 1978. Subcellular localization and distribution of phospholipase $A$ in liver and brain tissue. Adv. Prostaglandin Thromboxane Res. 3: 55-67.

44. Garcia, A., J. D. Newkirk, and R. D. Mavis. 1975. Lung surfactant synthesis. Biochem. Biophys. Res. Commun. 64: 128-135.

45. Wassef, M. K., Y. N. Lin, and M. I. Horowitz. 1978. Phospholipid deacylating enzymes of rat stomach mucosa. Biochim. Biophys. Acta. 528: 318-330.

46. Bereziat, G., C. Wolf, O. Colard, and J. Polonovik. 1978. Phospholipases of plasmic membranes of adipose tissue. Adv. Exp. Med. Biol. 101: 191-199.

47. Kunze, H., and E. Bohn. 1978. Phospholipase $A_{2}$ and prostaglandins in human seminal plasma. Adv. Prostaglandin Thromboxane Res. 3: 159-165.

48. Sahu, S., and W. S. Lynn. 1977. Characterization of phospholipase A from pulmonary secretions of patients with alveolar proteinosis. Biochim. Biophys. Acta. 489: 307-317.

49. Record, M., J. Lloveras, G. Ribes, and L. Douste-Blazy. 1977. Phospholipases $A_{1}$ and $A_{2}$ in subcellular fractions and plasma membranes of Krebs II ascites cells. Cancer Res. 37: 4372-4377.

50. Lloveras, J., M. Record, G. Ribes, and L. Douste-Blazy. 1978. Phospholipases A of Krebs II ascites cells. Adv. Exp. Med. Biol. 101: 185-190.

51. Franson, R., R. Dobrow, J. Weiss, P. Elsbach, and W. B. Weglicki. 1978. Isolation and characterization of a phospholipase $A_{2}$ from an inflammatory exudate. $J$. Lipid Res. 19: 18-23.

52. Weiss, J., R. Franson, S. Bechendite, K. Schmeidler, and P. Elsbach. 1975. Partial characterization and purification of a rabbit granulocyte factor that increases permeability of Escherichia coli. J. Clin. Invest. 55: 33-42.

53. Verger, R., J. Rietsch, M. C. E. van Dam Mieras, and G. H. de Haas. 1976. Comparative studies of lipase and phospholipase $\mathrm{A}_{2}$ acting on substrate monolayers. J. Biol. Chem. 251: 3128-3133.

54. Magee, W. L., J. Gallai-Hatchard, H. Sanders, and R. H. S. Thompson. 1962. The purification and properties of phospholipase A from human pancreas. Biochem. J. 83: 17-25.

55. Wu, T-W., D. O. Tinker. 1969. Phospholipase $A_{2}$ from Crotalus atrox venom. Biochemistry. 8: 1558-1568.

56. Joubert, F. J., and S. van der Walt: 1975. Naja melanotenca (forest cobra) venom. Purification and some properties of phospholipases A. Biochim. Biophys. Acta. 379: 317-328.

57. Rock, C. O., and F. Snyder. 1975. Rapid purification of phospholipase $\mathrm{A}_{2}$ from Crotalus adamanteus venom by affinity chromatography. J. Biol. Chem. 250: 65646566 .

58. Wells, M. A., and D. J. Hanahan. 1969. Studies on phospholipase A. Biochemistry. 8: 414-424.

59. Borgstrom, B. 1976. Lipid Absorption: Biochemical and Clinical Aspects. University Park Press, Baltimore. 6572.

60. Scow, R. O., Y. Stein, and O. Stein. 1967. Incorporation of dietary lecithin and lysolecithin into lymph chylomicrons in the rat. J. Biol. Chem. 242: 4919-4924.

61. Arnesjo, B., A. Nilsson, J. Barrowman, and B. Borgstrom. 1969. Intestinal digestion and absorption of cholesterol and lecithin in the human. Scand. J. Gastroenterol. 4: 653-665.

62. Belleville, J., and J. Clement. 1968. Comparison de l'activité phospholipasique A. de préparations de pancréas et de suc pancréatique sur les phospholipides extraits du jaune d'veuf. C. R. Acad. Sci.(Paris). 266: 959962.

63. Smith, H. W. 1965. Observations on the flora of the alimentary tract of animals and factors affecting its composition. J. Pathol. Bacteriol. 89: 95-122.

64. Meyer, H., W. C. Puijk, R. Dijkman, M. E. L. Foda van der Hourn, F. Pattus, A. J. Slotboom, and G. H. de Haas. 1979. Comparative studies of tyrosine modification in pancreatic phospholipases. Biochemistry. 18: 3589-3597.

65. Dutilh, C. E., P. J. van Doren, F. Verheul, and G. H. de Haas. 1975. Isolation and properties of phospholipase $\mathrm{A}_{2}$ from ox and sheep pancreas. Eur. J. Biochem. 53: 91-97.

66. Dobbins, W. O., and J. M. Ruffin. 1967. A light and electron-microscopic study of bacterial invasion in Whipple's disease. Am. J. Pathol. 51: 225-242.

67. de Haas, G. H., N. M. Postema, W. Nieuwenhuizen, and L. L. M. van Deenen. 1968. Purification and properties of phospholipase A from porcine pancreas. Biochim. Biophys. Acta. 159: 103-117.

68. van den Bosch, H., A. J. Aarsman, and L. L. M. van Deenen. 1974. Isolation and properties of a phospholipase $A_{1}$ activity from beef pancreas. Biochim. Biophys. Acta. 348: 197-209.

69. Kwong, W. K. L., B. Seetharam, and D. H. Alpers. 1978. Effect of exocrine pancreatic insufficiency on small intestines in the mouse. Gastroenterology. 74: 1277-1282. 